\title{
RANCANG BANGUN SOLAR CHARGE CONTROLLER MENGGUNAKAN SYNCRONOUS NON-INVERTING BUCK-BOOST CONVERTER PADA PANEL SURYA 50 WATT PEAK (WP) BERBASIS ARDUINO NANO V3.0
}

\author{
Irfan Mahrubi ${ }^{1}$, Jusuf Bintoro ${ }^{2}$ dan Wisnu Djatmiko ${ }^{3}$ \\ 1,2,3 Prodi Pendidikan Teknik Elektronika Fakultas Teknik Universitas Negeri Jakarta \\ Email: ${ }^{1}$ mahrubiirfan@gmail.com, ${ }^{2}$ wisnu.djatmiko@gmail.com, 3 i_bintoro_2012@yahoo.com
}

\begin{abstract}
Abstrak- Penelitian ini bertujuan untuk merancang bangun rangkaian synchronous non-inverting buck-boost converter (SNIBBC) untuk solar charge controller guna melakukan manajemen pengisian baterai dan manajemen beban dengan menggunakan Arduino Nano V3.0 ATMega 328. Rancang bangun rangkaian synchronous noninverting buck-boost converter (SNIBBC) menggunakan empat mosfet yang bekerja secara saling singkron dengan dikontrol oleh pulsa PWM dari Timer1 arduino nano V3.0 ATMega 328 dengan frekuensi 10KHz menggunakan ic driver mosfet IR2104. Proses pengisian baterai oleh solar charge controller menggunakan tiga tahap pengisian yaitu bulk charge, absorption charge, dan float charge. Hasil pengujian menunjukan bahwa rangkaian SNIBBC dapat mengisi baterai lead-acid $12 \mathrm{~V}$ 5Ah dengan tegangan berusaha dijaga mendekati $15 \mathrm{~V}$ dengan rata-rata tegangan kelaran 14.97V. Pengujian solar charge controller dengan rangkaian inti SNIBBC dan dengan tiga tahap pengisian telah dapat mengisi baterai lead-acid 12V 5Ah dalam waktu 8 jam. Baterai yang digunakan dapat bertahan dengan dibebankan oleh beban inverter dan lampu ac LED 5watt dengan total daya yang diserap beban dan inverter 9.36watt selama 6 jam penggunaan. Solar charge controller yang telah dibuat dapat mengontrol penyambungan dan pemutusan hubungan antara baterai dengan beban berupa inverter dan beban ac dengan bantuan rangkaian saklar elektronik dengan relay.
\end{abstract}

Kata Kunci: Syncronous Non-Inverting Buck-Boost Converter, Solar Charge Controller, Panel Surya, Arduino Nano V3.0

\begin{abstract}
This reseach aims to design a synchronous non-inverting buck-boost converter (SNIBBC) for solar charge controller to perform battery charging and load management using Arduino Nano V3.0 ATMega 328. The synchronous non-inverting buck-boost converter (SNIBBC) uses four mosfets that work in sync with each other controlled by PWM pulses from Timer1 arduino nano V3.0 ATMega 328 with a frequency of $10 \mathrm{KHz}$ using the IR2104 mosfet driver ic. The process of charging the battery by solar charge controller using three stages of charging the bulk charge, absorption charge, and float charge. The test results show that the circuit of SNIBBC can charge the lead-acid $12 \mathrm{~V} 5 \mathrm{Ah}$ battery with the tried voltage closer to $15 \mathrm{~V}$ with an average voltage of $14.97 \mathrm{~V}$. The solar charge controller test with the SNIBBC core circuit and with three charging stages has been able to charge the 5V 5Ah lead-acid battery within 8 hours. The batteries used can withstand the charged by the inverter load and the 5watt LED ac lamp with total loaded power and 9.36watt inverters for 6 hours of use. Solar charge controller that has been made can control the connection and disconnection between the battery with the load of inverter and ac load with the help of electronic switch circuit with relay.
\end{abstract}

Keywords : $\quad$ Syncronous Non-Inverting Buck-Boost Converter, Solar Charge Controller, Solar Panel, Arduino Nano V3.0

\section{PENDAHULUAN}

Pemanfaatan energi non fosil menjadi topik yang sedang hangat dibicarakan dan dikembangkan baik di Indonesia maupun di negara-negara lain. Matahari menjadi salah satu sumber energi yang mampu menjadi sumber energi terbarukan untuk menghasilkan listrik.

Setelah pulih dari krisis moneter pada tahun 1998, Indonesia mengalami lonjakan hebat dalam konsumsi energi. Dengan keadaan yang seperti ini, diperkirakan kebutuhan listrik indonesia akan terus bertambah sebesar $4.6 \%$ setiap tahunnya, hingga diperkirakan mencapai tiga kali lipat pada tahun 2030 (Sutrisna dan Rahardjo, 2016).

Di dalam Kongres Ilmu Pengetahuan Nasional (Kipnas) IX tahun 2007 masalah Energi, air bersih dan pangan merupakan hal yang sangat mendesak untuk dijaga kesinambungannya terkait dengan masalah kemakmuran suatu bangsa. Pada aplikasinya 
pemanfaatan energi surya terbentur pada masalah klasik yaitu besarnya biaya yang diperlukan (Syamsu, 2013: 24)

Energi yang dikeluarkan oleh sinar matahari sebenarnya hanya diterima oleh permukaan bumi sebesar 69\% dari total energi pancaran matahari. Pada tengah hari yang cerah radiasi sinar matahari mampu mencapai $1000 \mathrm{Watt} / \mathrm{m}^{2}$. Masalah utama penggunaan energi surya untuk PLTS adalah ketersediannya. Energi matahari hanya tersedia di siang hari (Sutrisna dan Rahardjo, 2016).

Tegangan yang dapat dihasilkan dari sel surya silikon individu bervariasi antara $0.5 \mathrm{~V}$ sampai $0.6 \mathrm{~V}$. Tegangan keluaran sel surya hanya bergantung sedikit pada intensitas cahaya matahari, tetapi arus meningkat dengan intensitas radiasi cahaya matahari (Floyd, 2012: 26).

\section{METODOLOGI PENELITIAN}

Berdasarkan diagram alir penelitian seperti yang ditunjukan pada Gambar 1 tahap pertama yang dilakukan dalam penelitian adalah pencarian literature yang dilakukan guna mencari teori-teori yang berkaitan dengan topic penelitian untuk dipelajari. Tahap kedua adalah pembuatan rangkaian solar charge controller dengan SNIBBC pada tahap ini rangkaian SNIBBC yang sudah dibuat diuji untuk mengetahui apakah rangkaian sudah dapat digunakan untuk menaikan atau menurunkan tegangan atau belum, jika sudah maka akan lanjut ke tahap berikutnya dan jika belum maka akan dilakukan pengecekan ulang pada tahap ini. Tahap ketiga adalah pembuatan program pada arduino IDE, jika program pada tahap ini sudah berjalan dengan baik maka akan lanjut ke tahap berikutnya, dan jika tidakmaka akan dilakukan pengecekan ulang pada tahap ini. Tahap keempat adalah perakitan sistem, perakitan sistem terkait instalasi panel, baterai, inverter, dan relay serta LCD semuanya dihubungkan sehingga menjadi sebuah sistem. Tahap kelima adalah uji kerja sistem, pada tahap ini sistem yang sudah saling terhubung diuji dan kemudian berlanjut ke tahap keenam yaitu analisa, setelah hasil kerja sistem dianalisa berlanjut ke tahap ketujuh yaitu kesimpulan dan penelitian selesai.

A. Perancangan Syncronous Non-Inverting Buck-

Boost Converter (SNIBBC)

Dalam penelitian ini rangkaian synchronous noninverting buck-boost converter yang dibuat berdasarkan spesifikasi yang ada pada Tabel 1 .

Perhitungan nilai duty cycle $(D)$ dilakukan untuk dua kondisi, yaitu pada kondisi ketika tegangan masukan minimal dan ketika tegangan masukan maksimal, perhitungan menggunakan (Pers. 3.2) dan (Pers. 3.3)

$$
\begin{gathered}
D_{\text {max }}=\frac{V_{o}}{V_{o}+V_{I \min }}=\frac{15}{15+5}=0,750 \\
D_{\text {min }}=\frac{V_{o}}{V_{o}+V_{I \max }}=\frac{15}{15+30}=0,333
\end{gathered}
$$
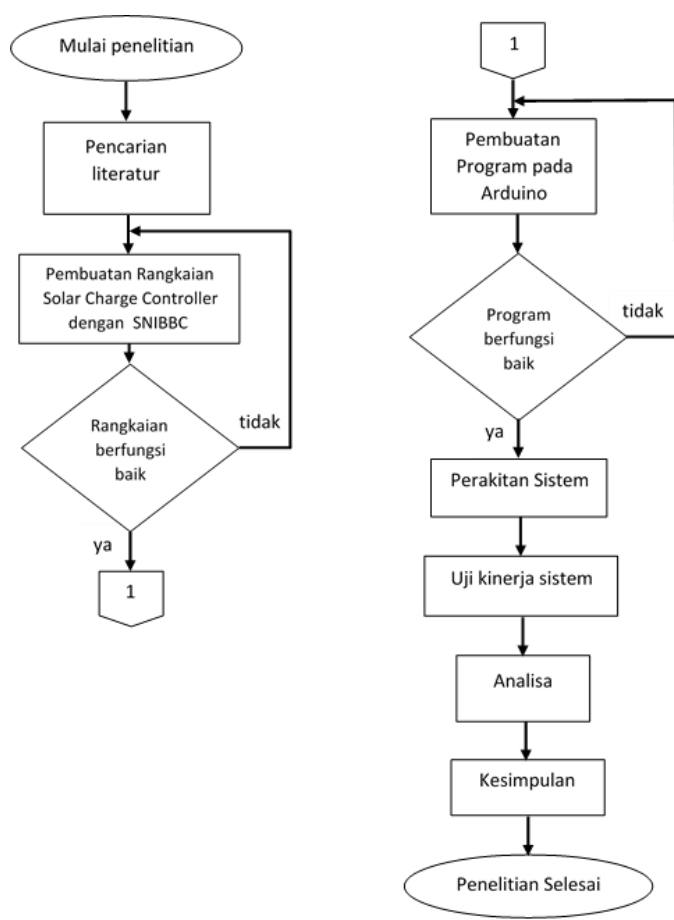

Gambar 1. Diagram Alir Penelitian

TABEL 1

SPESIFIKASI RANCANGAN SYNCHRONOUS NONINVERTING BUCK-BOOST CONVERTER

\begin{tabular}{|c|c|c|}
\hline Parameter & \multicolumn{2}{|c|}{ Nilai } \\
\hline$V_{O}$ & \multicolumn{2}{|c|}{$15 \mathrm{~V}$} \\
\hline \multirow{2}{*}{$V_{I}$} & $\min$ & maks \\
\cline { 2 - 3 } & $5 \mathrm{~V}$ & $30 \mathrm{~V}$ \\
\hline$I_{\text {Omaks }}$ & \multicolumn{2}{|c|}{$4 \mathrm{~A}$} \\
\hline$F$ switching & \multicolumn{2}{|c|}{$10 \mathrm{KHz}$} \\
\hline
\end{tabular}

Perhitungan nilai induktor $(L)$ dilakukan pada saat tegangan masukan maksimal dengan asumsi ripel arus pada induktor $\Delta I_{o}$ sebesar $8.2 \%$ dari arus keluaran maksimal 4A atau sebesar $0.33 \mathrm{~A}$, perhitungan menggunakan (Pers. 3.4) dilakukan untuk menentukan besar induktansi minimal induktor.

$$
L=\frac{V_{I \max } D_{\min }}{f \Delta I_{o}}=\frac{30 \times 0,333}{10000 \times 0,33}=3 \mathrm{mH}
$$

Perhitungan nilai kapasitor $(C)$ dilakukan pada saat nilai arus keluaran maksimal dengan asumsi ripel tegangan pada kapasitor $\Delta V_{o}$ sebasar $0.37 \%$ dari tegangan keluaran $15 \mathrm{~V}$ atau sebesar $0.055 \mathrm{~V}$, perhitungan menggunakan (Pers. 3.5) dilakukan untuk menentukan besar kapasitansi minimal kapasitor.

$$
C=\frac{I_{\text {omax }} D_{\max }}{f \Delta V_{o}}=\frac{4 \times 0,937}{10000 \times 0,055}=6.8 \mathrm{mF}
$$


Sehingga dipilih kapasitor $6800 u F$ dengan tegangan maksimum kapasitor $50 \mathrm{~V}$.

B. Rancangan Solar Charge Controller Menggunakan Syncronous Non-Inverting Buck-Boost Converter

Guna mengontrol empat mosfet yang saling singkron pada Gambar 2 maka digunakan IC driver mosfet IR2104. IC IR2104 adalah driver mosfet yang mengontrol dua mosfet yang tersusun secara high-side dan low-side secara singkron.

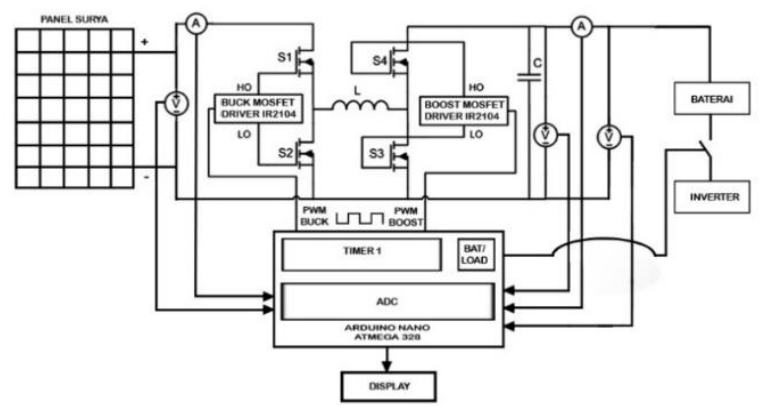

Gambar 2. Rancangan Solar Charge Controller Menggunakan Syncronous Non-Inverting Buck-boost Converter

\section{HASIL DAN PEMBAHASAN}

A. Analisa Data Penelitian

1) Pengecekan Pulsa PWM 10KHz Yang Dibuat Dengan Program Arduino

Pengecekan dilakukan pada kedua pin dari Timer1 yaitu pin 9 dan 10. Hasil pengecekan sinyal PWM ditunjukan pada Gambar 3 Pin 9 untuk PWM buck yang mengontrol driver mosfet buck dan pin 10 untuk PWM boost yang mengontrol driver mosfet boost.

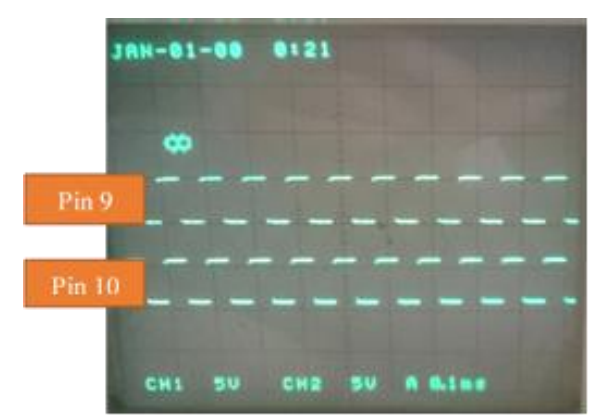

Gambar 3. Pulsa PWM dari pin 9 dan 10 dengan frekuensi $10 \mathrm{KHz}$

\section{2) Pengujian SNIBBC Untuk Melakukan Pengisian Baterai}

Pengujian dilakukan ketika tegangan baterai berada pada $2.0 \mathrm{~V}$ per-cell atau ketika tegangan baterai $12 \mathrm{~V}$ dengan tegangan masukan dari power suplai mulai dari $5 \mathrm{~V}-30 \mathrm{~V}$. Hasil pengujian ditunjukan pada Gambar 4.

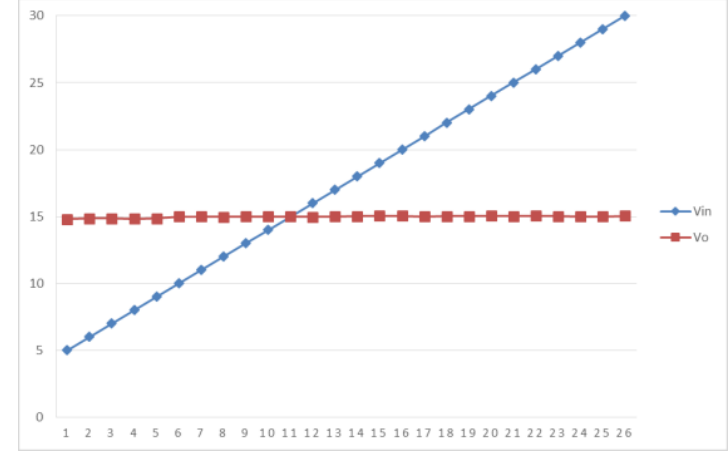

Gambar 4. Grafik Pengujian Pengisian Baterai Dengan Tegangan Masukan 5 - 30V Pada Beban Baterai Lead-Acid 12V/5AH Dengan Tagangan Pengisian Dijaga Pada 15V

3) Pengujian Penonaktifan MOSFET Ketika Rangkaian Mendapat Tegangan Masukan Kurang Dari $5 \mathrm{~V}$

Pengujian ini dilakukan untuk mengetahui apakah rangkaian yang telah dibuat sudah dapat dikontrol menggunakan ardunio guna menonaktifkan rangkaian SNIBBC dengan mengirimkan logika LOW dari pin digital 11 dan 12 arduino nano yang terhubung dengan kaki 3 dari kedua IC driver mosfet IR2104 yang berfungsi untuk menonaktifkan IC IR2104 sehingga mosfet tidak bekerja atau dalam keadaan off.

4) Pengujian Pengaktifan Mosfet Ketika Rangkaian Mendapat Tegangan Masukan

Lebih Dari 5 V

Pengujian ini dilakukan untuk mengetahui apakah rangkaian yang telah dibuat sudah dapat dikontrol menggunakan ardunio guna mengaktifkan rangkaian SNIBBC dengan mengirimkan logika HIGH dari pin digital 11 dan 12 arduino nano yang terhubung dengan kaki 3 dari kedua IC driver mosfet IR2104 yang berfungsi untuk mengaktifkan IC IR2104 sehingga mosfet bekerja.

5) Pengujian Solar Charge Controller Dengan Beban Baterai Lead-Acid 12V/5Ah

Pengujian dilakukan dengan mengamati proses pengisian baterai mulai dari tahap pertama pengisian atau bulk charge. Tahap ini akan berlangsung sampai tegangan baterai per-cell menjadi $2.4 \mathrm{~V}$ atau sampai tegangan baterai $14.4 \mathrm{~V}$. Tahap kedua atau tahap absorption charge dengan tegangan pengisian baterai dijaga pada $14.4 \mathrm{~V}$ selama satu jam. Tahap ketiga dengan float charge, dimana tegangan pengisian dijaga $13.5 \mathrm{~V}$ untuk menjaga baterai dari overcharging, menjaga baterai tetap dalam keadaan standby sampai digunakan kembali. Hasil dari pengujian ditunjukan pada Gambar 5. 


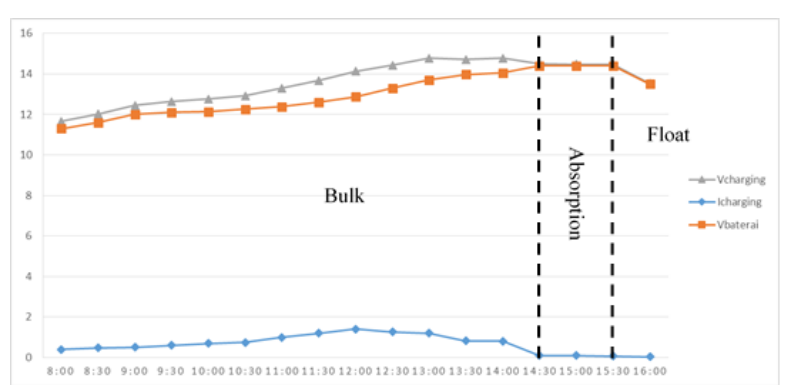

Gambar 5. Grafik Pengisian baterai dengan tiga tahap pengisian

6) Pengujian Saklar SA Dengan Relay Untuk Memutus Dan Menghubungkan Beban Inverter Dengan Baterai

Pengujian ini dilakukan untuk mengetahui apakah rangkaian yang telah dibuat sudah dapat dikontrol menggunakan ardunio guna menghubungkan antara baterai dengan beban (inverter) dan atau memutuskan hubungan antara baterai dengan beban. Dengan mengirim logika high pada bagian driver relay yang terhubung dengan pin digital 8 arduino nano.

7) Pengujian Lama Waktu Baterai Untuk

\section{Mensuplai Beban}

Berdasarkan spesifikasi baterai ketika penuh adalah $5 \mathrm{Ah}$ dengan tegangan $12 \mathrm{~V}$, maka daya yang dapat disalurkan baterai dalam satu jam adalah 60watt/jam. Arus yang mengalir dari baterai ke baban inverter dan lampu LED 5 watt adalah 0.78A, maka daya yang diserap oleh inverter dan lampu LED adalah $12 \mathrm{~V} \times 0.78 \mathrm{~A}$ atau sama dengan 9.36Watt

Berdasarkan perhitungan maka baterai akan habis dalam enam jam lebih empat puluh satu menit.

$$
\frac{60 \mathrm{watt}}{9.36 \mathrm{watt}} \times 1 \mathrm{jam}=6.41 \mathrm{jam}
$$

Berdasarkan pengamatan, sistem telah memutuskan hubunguan antara baterai dengan inverter dan lampu ketika tegangan baterai telah turun pada 11. Baterai telah mensuplai selama 6 jam.

\section{KESIMPULAN}

Pembuatan rangkaian Synchronous Non-Inverting

Buck-Boost Converter (SNIBBC) untuk solar charge controller menggunakan 4 mosfet yang bekerja saling singkron dengan bantuan IC driver mosfet yang dikontrol dengan dua buah sinya PWM dari arduino nano pada Timer1 ATMega 328 yang ada pada pin 9 dan 10 arduino nano guna menaikan dan atau menurunkan tegangan masukan. Hasil pengujian menunjukan bahwa rangkaian SNIBBC dapat mengisi baterai lead-acid $12 \mathrm{~V} 5 \mathrm{Ah}$ dengan tegangan berusaha dijaga mendekati $15 \mathrm{~V}$ dengan rata-rata tegangan kelaran 14.97V. Pengujian solar charge controller dengan rangkaian inti SNIBBC dan dengan tiga tahap pengisian telah dapat mengisi baterai lead-acid 12V 5 Ah dalam waktu 8 jam. Baterai yang digunakan dapat bertahan dengan dibebankan oleh beban inverter dan lampu ac LED 5watt dengan total daya yang diserap beban dan inverter 9.36watt selama 6 jam penggunaan. Solar charge controller yang telah dibuat dapat mengontrol penyambungan dan pemutusan hubungan antara baterai dengan beban berupa inverter dan beban ac dengan bantuan rangkaian saklar elektronik dengan relay.

\section{REFERENSI}

[1] Arduino.cc. [terhubung berkala]. [12 januari 2016].

[2] Chargertek,inc. (2015). Battery Charger Basics. [terhubung berkala] http://www.chargetek.com/basic-information.html. [15 Okt 2016].

[3] Fakultas Teknik. (2015). Buku Panduan dan Penyusunan skripsi dan Non Skripsi. Jakarta: Fakultas Teknik, Universitas Negeri Jakarta.

[4] Floyd, Thomas L. (2012). Electronic Devices (Electron Flow Version). New Jersey: Prentice Hall.

[5]Gautam, Aditya Raw., Deshpande, D.M., Suresh, Arisutha., \& Mittal, Arvind. (2013). A Double Input DC to DC BuckBoost Converter for Low Voltage Fotovoltaic/Wind Systems. International Journal of ChemTech Reseach, 5: 1018-1020.

[6] Harsokoesomo, H. Darmawan. (2000). Pengantar Perancangan Teknik. Bandung : Institut Teknologi Bandung.

[7] Hart, Daniel W. (2011). Power Electronics. New York McGraw-Hill

[8] Indonesia Alami Lonjakan Dalam Konsumsi Energi www.alpensteel.com/article/114-101-energi-terbarukanrenewable-energy/2966)

[9] Kazimierczuk, Marian K. (2015). Pulse-Width Modulated DCDC Power Converter. USA : John Wiley \& Sons, Inc

[10] Khakam, Maula Nurul. (2013). Desain dan Implementasi Sistem Manajeman Pengisian Baterai dan Beban pada Pembangkit Listrik Mandiri Menggunakan Syncronous Non-Inverting Buck-Boost DC-DC Converter. Surabaya : ITS

[11] LabVolt. (2010). DC Power Electronics.

[12] LabVolt. (2010). Lead-Acid Batteries.

[13] Qazi, Salahuddin. (2017). Standalone Photovoltaik (PV)Systems for disaster relief and remote Areas. United State : Elsevier

[14] Rashid, Muhammad H. Power Electronics Circuits, Device and Applications. New Jersey : Prentice Hall

[15] Rashid, Muhammad H. (2015). Alternative energy in Power Electronics. USA : Elsevier

[16] Sugiono. (2014). Metode Penelititan Kuantitatif, Kualitataif dan $R \& D$. Bandung: Alfabeta.

[17] Syamsu, Iqbal. (2011). Perancangan Battery Control Unit (BCU) Pada Modul Panel Surya 50 Watt Peak (WP). Pusat Penelitian Elektronika dan Komunikasi LIPI.

[18] Tim Penyusun KBBI. (2008). Kamus Besar Bahasa Indonesia. Jakarta : Departement Pendidikan Nasional. 